\title{
The earliest occurrence and remarkable stasis of the family Bostrichidae (Coleoptera: Polyphaga) in Cretaceous Charentes amber
}

\author{
David Peris, Xavier Delclòs, Carmen Soriano, and Vincent Perrichot
}

\begin{abstract}
A new fossil species of auger beetle (Coleoptera: Bostrichidae), preserved in midCretaceous (Albian-Cenomanian) amber from south-western France, is described as Stephanopachys vetus Peris, Delclòs et Perrichot sp. $\mathrm{n}$. The species is the earliest fossil bostrichid discovered to date, but is remarkably similar to Recent species of the genus Stephanopachys, supporting long morphological conservation in wood boring beetles. The specimen is fossilized in fully opaque amber and was imaged in 3D using propagation phase-contrast $\mathrm{X}$-ray synchrotron microtomography. Based on the ecology of extant related species habits, it is suggested that $S$. vetus sp. n. was a primary succession pioneer following wildfires in mid-Cretaceous forests. The fossil record of the family is reviewed.
\end{abstract}

David Peris. Departament d'Estratigrafia, Paleontologia i Geociències Marines and Institut de Recerca de la Biodiversitat (IRBio), Facultat de Geologia, Universitat de Barcelona (UB), Martí i Franquès s/n, 08028 Barcelona, Spain. daperce@gmail.com, david.peris@ub.edu

Xavier Delclòs. Departament d'Estratigrafia, Paleontologia i Geociències Marines and Institut de Recerca de la Biodiversitat (IRBio), Facultat de Geologia, Universitat de Barcelona (UB), Martí i Franquès s/n, 08028 Barcelona, Spain. xdelclos@ub.edu

Carmen Soriano. European Synchrotron Radiation Facility, 6 rue Jules Horowitz, BP 220, Grenoble 38000, France.carmen.soriano@gmail.com

Vincent Perrichot. Université de Rennes 1, UMR CNRS 6118 Géosciences \& OSUR, 35042 Rennes cedex, France. Email: vincent.perrichot@univ-rennes1.fr

Keywords: Beetle; new species; Charente-Maritime; France; palaeoenvironment; synchrotron imaging

PE Article Number: 17.1.14A

Copyright: Palaeontological Association March 2014

Submission: 2 June 2013. Acceptance: 12 March 2014

Peris, David, Delclòs, Xavier, Soriano, Carmen, and Perrichot, Vincent. 2014. The earliest occurrence and remarkable stasis of the family Bostrichidae (Coleoptera: Polyphaga) in Cretaceous Charentes amber. Palaeontologia Electronica Vol. 17, Issue 1;14A; 8p; palaeo-electronica.org/content/2014/706-new-cretaceous-auger-beetle 


\section{INTRODUCTION}

Coleoptera is one of the most abundant arthropod orders found as fossil inclusions in Cretaceous ambers (Grimaldi et al., 2000; Ross et al., 2010). This fact is largely due to the saproxylic or wood-boring habits of many polyneopteran families (Fowles et al., 1999; Toivanen and Kotiaho, 2009). Some groups with close affinities for resin-producing trees, e.g., Ptinidae or Curculionidae, are particularly prone to entrapment in resin and thus might be over-represented in some amber deposits (Rasnitsyn and Quicke, 2002; Peris et al., 2014). Some authors even suggested that tree wounds resulting from attacks by wood-boring beetles might have been a major process in the massive resin production that occurred at some points in the geological times (Martínez-Delclòs et al., 2004; McKellar et al., 2011; Seyfullah et al., 2012). The curculionid subfamilies Scolytinae and Platypodinae, for instance, are a prominent group in Early Miocene Dominican amber (Poinar and Poinar, 1999; Penney, 2010), and McKellar et al. (2011) suggested these weevils might have played a prominent role in the resin production by Hymenaea Linnaeus, 1753 trees during the formation of Early Miocene Dominican amber, as well as by Cupressaceous trees during the formation of Turonian New Jersey (NJ) amber. However, Platypodinae is lacking in Cretaceous ambers, and only two Scolytinae are known from the Upper Albian-Cenomanian Burmese amber (Cognato and Grimaldi, 2009) and one from the Aptian Lebanese amber (Kirejtshuk et al., 2009). Both groups have yet to be found from $\mathrm{NJ}$ amber. In contrast, Ptinidae is another wood-borer family of beetles frequently encountered in NJ amber (Grimaldi et al., 2000), which may induce tree wounds described in McKellar et al. (2011) (Peris et al., 2014).

None of the subfamilies mentioned above has been recorded from French Cretaceous amber to date. Herein we describe a new species of Bostrichidae from mid-Cretaceous amber of Charentes, south-western France. Most bostrichid larvae are wood-borers and in some cases the adult female may cause the death of the trees utilized by larvae (Ivie, 2002). It is the first definitive Cretaceous Bostrichidae and the earliest record of the family, which is otherwise known exclusively from Tertiary fossils (Larsson, 1978; Solórzano-Kraemer, 2007; Poinar, 2013).

\section{MATERIAL AND METHODS}

The description of the new species is based on a single specimen found in a piece of opaque amber which was collected in the Font-de-Benon quarry, about $1 \mathrm{~km}$ east of Archingeay, in Charente-Maritime, south-western France. Two amber levels were exploited in this outcrop (Perrichot et al., 2010): the level A1sl-A which is the most fossiliferous of all French Cretaceous amber-bearing strata and is dated as latest Albian or earliest Cenomanian; and the level A2a which contains fewer and less fossiliferous amber and is dated as early Cenomanian. The bostrichid studied herein originates from level A1sl-A. Details on the geology, palaeobiota and palaeoenvironment of this and other Charentes amber deposits can be found elsewhere (Néraudeau et al., 2002; Girard et al., 2009; Perrichot et al., 2010).

The holotype is complete, without taphonomic distortion, but is preserved in a piece of entirely opaque, milky amber. Therefore, it is not visible by conventional optical methods, and instead it was detected and imaged using propagation phasecontrast X-ray synchrotron imaging techniques (PPC-SR $\mu C T$ ) developed for the survey of opaque amber (Tafforeau et al., 2006; Lak et al., 2008; Soriano et al., 2010) at the European Synchrotron Radiation Facility (ESRF) in Grenoble. The specimen was imaged at the beamline ID19 using 1500 projections obtained through 180 degrees rotation of the sample (see technical details in Lak et al., 2008 and Soriano et al., 2010). After acquisition, the volume was constructed using a filtered backprojection algorithm adapted for local tomography applications (PyHST software, ESRF) followed by a three-dimensional processing using a manual region growing protocol in VGStudioMax software (version 2.1, Heidelberg). The amber piece containing the original specimen ('holotype') is held with a 3D model in ABS plastic ('plastotype') in the collection of the Geological Department and Museum of the University Rennes 1, France, under the collection number IGR.ARC-270 (scan ESRF A-039). Measurements (all in $\mathrm{mm}$ ) were obtained using the scale provided with the synchrotron imaging.

\section{SYSTEMATIC PALAEONTOLOGY}

Order COLEOPTERA Linnaeus, 1758

Suborder POLYPHAGA Emery, 1886

Family BOSTRICHIDAE Latreille, 1802

Subfamily DINODERINAE Thompson, 1863

Genus STEPHANOPACHYS Waterhouse, 1888 
Type species. Stephanopachys substriatus Paykull, 1800

Species Stephanopachys vetus Peris, Delclòs et Perrichot sp. $\mathrm{n}$. Figure 1

zoobank.org/4A7D5C82-E961-4C77-BE7B-4C133C9B745F

Type material. Holotype IGR.ARC-270, a complete specimen (sex unknown) preserved in a piece of fully opaque amber, imaged by synchrotron microtomography (scan ESRF A-039); deposited in the amber collection of the Geological Department and Museum of the University Rennes 1 (France).

Type locality. Font-de-Benon quarry, ca. $1 \mathrm{~km}$ east of Archingeay, Charente-Maritime, France.

Age. Mid-Cretaceous, latest Albian or earliest Cenomanian, lithological level A1sl-A sensu Perrichot et al. $(2010)=A 1$ sl1 sensu Néraudeau et al. (2002).

Etymology. The specific epithet is the Latin vetus meaning 'ancient'.

Diagnosis. Tiny species; pronotum reduced, convex and not gibbose; pronotal disc granulose but the fore margin of pronotum without marginal teeth; antennae with 11 antennomeres, with a loose three-segmented club; metacoxa horizontally oriented, not touching elytra and not excavate; pentameric tarsal formula with fifth tarsomere longer than the preceding four combined; elytra seriate and strongly punctate, not truncate apically, row of irregularly shaped granules on interstriate elytral disk.

Description. Total body length 2.2 , greatest width 0.8 ; ratio of body length to greatest width 2.75 ; maximum pronotal length 0.6 , medium pronotal width 0.7 , posterior pronotal width 0.6 ; elytral length 1.5 , elytral width 0.8 . Body strongly convex, with parallel sides; cylindrical transversal section.

Head from above entirely concealed by pronotum; transverse occipital ridge or carina absent; compound eyes strongly protuberant laterally, entire, without notch; vertex and clypeus granulose. Antennal insertions lateral; widely separated, close to mandibles; frontoclypeal suture distinctly impressed, straight; anterior edge of clypeus straight; small, transverse labrum not covering the mandibles, the apex slightly convex; mandible short and broad; mandibular apex moderately curved, unidentate. Antenna with 11 antennomeres (Figure 1.5) each distinctly separated, gradually increasing in size, capitate, with three-segmented free club, which corresponds to 0.3 antennal length (shorter than five preceding antennomeres), not reaching middle of prothorax when directed backward. Scape globular, slightly bigger than pedicel, pedicel with ovate shape; antennomere III is the thinnest and shortest, half as long as pedicel; antennomere IV to VIII equal in shape, transverse, wider than long; antennomere VIII slightly bigger than pedicel, transversally oblate in shape; antennomere $\mathrm{X}$ wider than $\mathrm{XI}$; antennomere $\mathrm{XI}$ the longest segment, narrower than preceding one, tapering at apex.

Pronotal length equal to greatest pronotal width; prothorax widest medially; sides of prothorax strongly curved and not expanded; base of prothorax slightly narrower than elytral bases, and greatest prothoracic width slightly narrower than greatest elytral width; pronotum slightly cowled, but not gibbose; anterior margin of the pronotum strongly rounded and smooth, without teeth or sharp granules along it (Figure 1.4); posterior angles of pronotum rounded; pronotal disc densely and coarsely granulose, rough; the granules on basal half strongly elevated; anterior portion of prosternum at midline longer than prosternal process, anterior edge of prosternum not produced anteriorly; prosternal process incomplete, acute apically, not extending between procoxae to mesoventrite; procoxae conical and projecting well below prosternum. Mesocoxa conical and projecting; mesocoxal cavities contiguous medially; mesocoxae very narrowly separated, by less than diameter of coxal cavity. Metaventral median line long; metasternum longer than first abdominal ventrite, slightly convex and strongly punctuate. Metacoxae horizontally oriented, narrowly separated, not more than mesocoxae diameter, metacoxae extending laterally, but not reaching elytra, completely separated from metaventrite by suture (Figure 1.1); anterior process of metendosternite short; apical portion of metendosternite only slightly emarginated.

Femoral attachment of trochanter oblique; tibiae wider apically, outer edge of tibiae with distinct teeth; tarsi shorter than tibiae; pentameric tarsal formula. From first to fourth tarsomere equally, apical tarsomere longer than all preapical tarsomeres together (Figure 1.2); tarsal claws simples, subequal in length and shape.

Ratio of elytral length to greatest elytral width 1.88; ratio of elytral length to pronotal length 2.5 . Scutellum well developed, anteriorly simple and posteriorly truncate, with quadrate shape; elytral surface with ten rows of conspicuous punctures about as wide as intervals between them; interstri- 


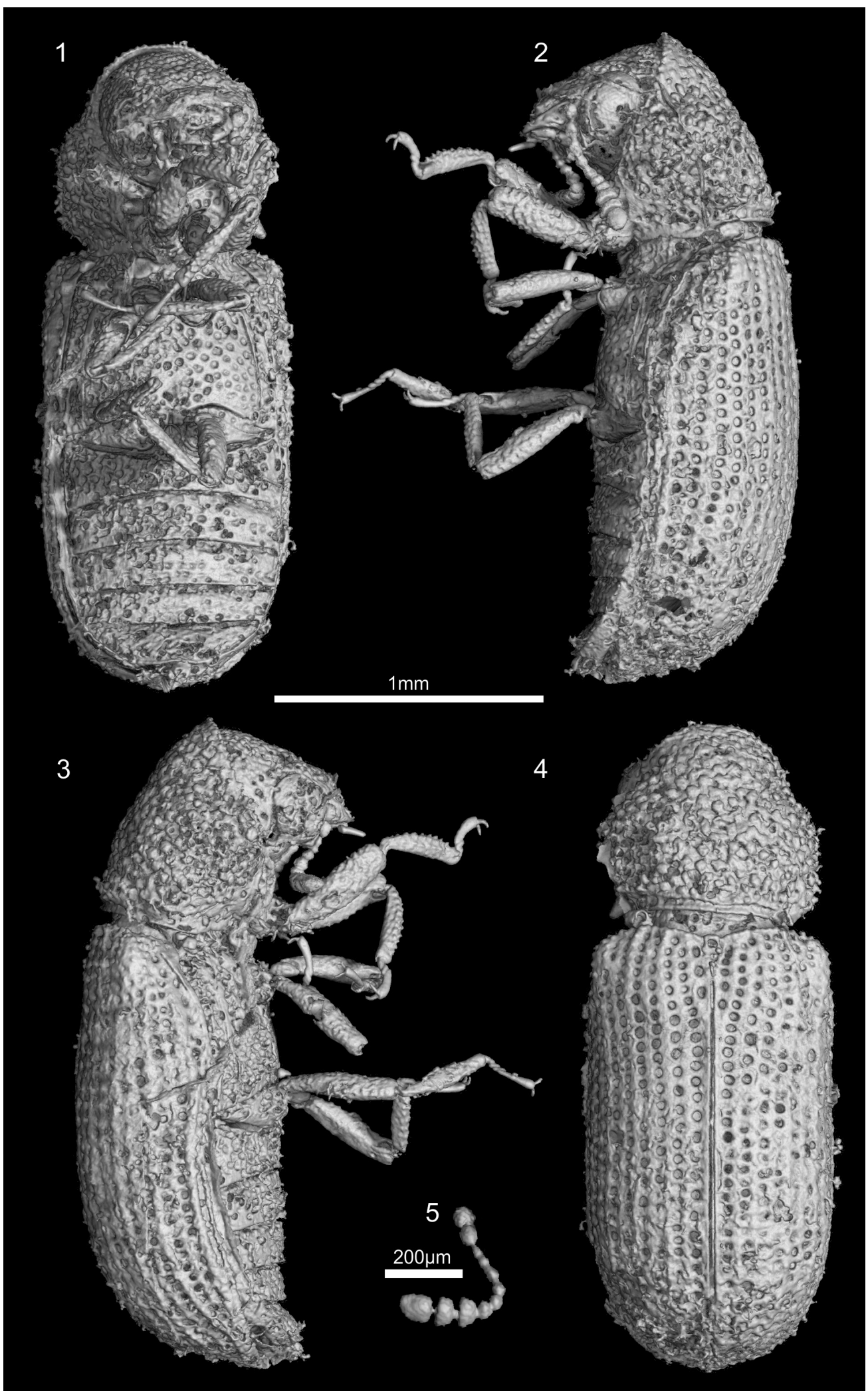

FIGURE 1. Three-dimensional reconstruction of Stephanopachys vetus sp. n., (holotype IGR.ARC-270), from Cretaceous French amber, as obtained from PPC-SR $\mu$ CT at BM19 beamline, in the ESRF, Grenoble. 1.1 Ventral view; 1.2 left lateral view; 1.3 right lateral view; 1.4 dorsal view; 1.5 antennae detail. Scale bar $1.1-1.4$ equals $1 \mathrm{~mm} ; 1.5$ is 200 $\mu \mathrm{m}$. 
ate rows granulose; lateral edge of elytra straight, and not truncate apically, with granulose declivity, not punctate (at least not strongly punctate as the rest of elytra) (Figure 1.3).

Five abdominal ventrites; first ventrite not completely divided by metacoxae; abdominal process narrowly rounded; moderately convex ventrites and entire sutures; length and width decrease from first to fifth; abdominal surface coarsely punctate.

\section{DISCUSSION}

\section{Systematics}

Stephanopachys vetus $\mathrm{sp} . \mathrm{n}$. has the following features of the family Bostrichidae, as given by Fisher (1950) and Ivie (2002): 1) body elongate, 2) cylindrical in form, 3) straight antenna with a free three-segmented club (which distinguish them from the Scolytinae) and 4) five segmented tarsi. Within the family, the specimen can be placed in the subfamily Dinoderinae for the following characters: 1) head deeply inserted in the prothorax, not visible from above, 2) pronotum convex and rounded anteriorly, not margined laterally and 3) tarsi not longer than tibiae (Lesne, 1896; Fisher, 1950). This subfamily is comprised of six genera (Fisher, 1950; Ivie, 2002), and according to Lesne (1897), the new fossil can be placed in the Recent genus Stephanopachys Waterhouse, 1888 for the following characters: 1) clypeus at sides longer than labrum, 2) pronotum posteriorly without a row of small tubercles, 3) antennal funicle robust, 4) apical segment of antennal club narrower than preceding segment, and 5) pronotum broadly rounded in front. The new fossil does differs from typical Stephanopachys by possession of 11 antennomeres, and a fore margin of the pronotum without marginal teeth. Although these characters are considered by some authors as sufficiently different to warrant a new genus, a conservative approach has been taken in this study and it is placed in the Recent genus Stephanopachys.

Lesne (1897) and Fisher (1950) described several Stephanopachys species. Based on longitudinal rows of elevated granules on intervals along elytra, Stephanopachys vetus sp. $\mathrm{n}$. is hardly distinguished from the modern species Stephanopachys amplus Casey, 1898 and S. substriatus Paykull, 1800. However, S. vetus sp. n. differs from S. amplus by: 1) pronotum convex and not gibbose, 2) pronotum small and 3 ) row of irregularly shaped granules on interstriate elytral disk. Additionally $S$. vetus sp. $\mathrm{n}$. is erected and differs from $S$. amplus and $S$. substriatus by the following set of characters: 1) antennae 11-segmented, 2) apical margin of pronotum without marginal teeth and 3) body length shorter.

Compared to all bostrichid subfamilies, the Dinoderinae is the most stable in the phylogenetic analysis of Liu and Schönitzer (2011). It appears as a relict group that originated 100 m.y.a. or more and remained remarkably stable over the time. The stable and sheltered habitat of those beetles together with their tiny size might have promoted the stability of this lineage. This is not an isolated example among insects, as demonstrated by other recent findings of extant genera with Cretaceous representatives in the Diptera (Sinclair and KirkSpriggs, 2010) and the staphylinid and ptinid Coleoptera (Chatzimanolis et al., 2013; Peris et al., 2014).

\section{Palaeobiology}

Adult Bostrichidae are wood-borers into trunks, branches or dead trees, digging galleries in which they lay eggs (Ivie, 2002). The body shape of most bostrichids is rather stout with stout legs and teeth on the external side of the tibiae as adaptations to a wood-boring life (Cymorek, 1968). Even though bostrichids are known for their xylophagous way of life, the wood-dwelling part of the life cycle is not the same for every bostrichid. They may bore into the wood as adults or only during the larval pupal stages. In Lyctinae the females may use broken surfaces or fissures of the wood to lay their eggs. These differences in adult life style are correlated with differences in adult morphology (Liu and Schönitzer, 2011).

Most Dinoderinae feed on sapwood (Lawrence, 2010) and Lesne (1897) described Stephanopachys living under trunks of dead conifers. Stephanopachys substriatus and S. linearis Kugelann, 1792 were described as fire dependent species (Johansson et al., 2011), particularly attracted by young trees damaged by wildfires (Hyvärinen et al., 2006). They are usually found under the bark and sapwood of Pinus Linnaeus, 1753, rarely under the bark of dried up stumps and trunks of Picea (D. Don) Loudon, 1838 and Abies Miller, 1754 (Jurc et al., 2008). In Europe Pinus sylvestris Linnaeus, 1753 is especially susceptible to its attacks (Fisher, 1950).

Martínez-Delclòs et al. (2004) suggested ancient high-devastating fires producing bark splitting as a possible reason for the high output of Cretaceous resin worldwide. This idea is supported by the presence of charcoal or fusinite in many 
amber-bearing levels (Grimaldi et al., 2000; Najarro et al., 2010), even sometimes as inclusions within amber (Peñalver and Delclòs, 2010; Perrichot, 2004: figure 3). This hypothesis is also consistent with inclusions embedded in Spanish amber, such as anaxyelid woodwasps (OrtegaBlanco et al., 2008) or gleicheniacean ferns trichomes (Pérez-de la Fuente et al., 2012), both taxa related with primary succession pioneers following wildfires.

It is possible that Stephanopachys vetus sp. $\mathrm{n}$. was also a primary succession pioneer in mid-Cretaceous palaeoenvironment and was trapped in sticky resin drops while searching some scorched or dead conifer debris. It is likely that the large amount of resin production during the Cretaceous resulted from a combination of processes, including fires, xylophagy and microbial or fungal infestation (Seyfullah et al., 2012).

\section{Fossil record}

Stephanopachys vetus sp. $\mathrm{n}$. is the first definitive Cretaceous and earliest record of the family Bostrichidae which is otherwise known from few Tertiary deposits only. Protapate contorta Wickam, 1912, was described from Early Oligocene shales of Florissant, Colorado (Wickam, 1912), and is the only bostrichid known from a compression fossil. Discoclavata dominicana Poinar, 2013, of the subfamily Bostrichinae, was recently described from Miocene Dominican amber (Poinar, 2013). Bostrichids were also recorded from Miocene Mexican amber but remain undetermined (Poinar, 1992) except one specimen possibly assigned in the dinoderine genus Prostephanus Lesne, 1898, but yet waiting for a formal description (SolórzanoKraemer, 2007). The only other fossil specimens are mentioned from Eocene Baltic amber but they have remained undescribed until now (Poinar, 1992): the genera Apate Fabricius, 1775, and Bostrychus Geoffroy, 1762 were recorded by Handlirsch (1906-1908), then by Spahr (1981) who also mentioned the presence of Rhyzopertha Stephens, 1830, as well as Lyctus Fabricius, 1792. Placement of the latter remains controversial (Lawrence and Newton, 1995; Ivie, 2002; Bouchard et al., 2011; Liu and Schönitzer, 2011) and it is alternatively considered in its own family Lyctidae (Lawrence, 2010). Finally, bostrichoid beetles are recorded in Cretaceous New Jersey and Burmese amber, but they cannot be confidently assigned to any of the existing family (Grimaldi and Engel, 2005). True Bostrichidae have thus a scarce fossil record while their wood-boring ecology makes them particularly prone to engulfment in resin. In contrast, the Ptinidae, another family of beetles with similar behavior, have a higher Cretaceous record with seven specimens studied from ambers of New Jersey and Spain (Peris et al., 2014) and three more unstudied specimens from New Jersey. However, bostrichids are also very scarce in modern ecosystems (Liu and Schönitzer, 2011), and it is possible that a similar situation prevailed in the Cretaceous.

\section{ACKNOWLEDGEMENTS}

The authors are very grateful to the European Synchrotron Radiation Facility for granting access to the ID19 beamline, and to P. Tafforeau for assistance and guidance during the imaging process. Additional thanks are extended to two anonymous reviewers for their helpful feedback. This work is part of the Ph.D. dissertation of the first author, supported by an FPU grant from the Spanish Education Ministry. It is a contribution to the project $\mathrm{n}^{\circ}$ CGL2011-23948 entitled "El ámbar de España: Un estudio pluridisciplinar II," from the Spanish Ministry of Economy and Competitivity (Ministerio de Economía y Competitividad), and a contribution to the French project Interrvie NOVAMBRE (CNRSINSU grant to D. Néraudeau). Work from C. Soriano at the ESRF was partly supported by grant AMBRACE ( $n^{\circ}$ BLAN07-1- 184190) from the French National Research Agency.

\section{REFERENCES}

Bouchard, P., Bousquet, Y., Davies, A.E., Alonso-Zarazaga, M.A., Lawrence, J.F., Lyal, C.H., Newton, A.F., Reid, C.A.M., Schmitt, M., Slipinski, S.A., and Smith, A.B.T. 2011. Family-group names in Coleoptera (Insecta). Zookeys, 88:1-972.

Casey, T.L. 1898. Studies in the Ptinidae, Cioidae, and Sphindidae of America. Journal of the New York Entomological Society, 6:61-93.

Chatzimanolis, S., Newton, A.F., Soriano, C., and Engel, M.S. 2013. Remarkable stasis in a phloeocharine rove beetle from the Late Cretaceous of New Jersey (Coleoptera, Staphylinidae). Journal of Paleontology, 87:177-182.

Cognato, A.I. and Grimaldi, D. 2009. 100 million years of morphological stasis in bark beetles (Coleoptera: Curculionidae: Scolytinae). Systematic Entomology, 34:93-100.

Cymorek, S. 1968. Adaptations in wood-boring insects: Examples of morphological, anatomical, physiological and behavioural features. British Wood Preserving Association Annual Convention Record, 18:161180. 
Emery, C. 1886. Ueber Phylogenie und Systematik der Insekten. Biologisches Centralblatt, 5:648-656.

Fabricius, J.C. 1775. Systema Entomologiae, sistens Insectorum classes, ordines, genera, species, adiectis synonymis, locis, descriptionibus, observationibus. Kortii, Flensburgi et Lipsiae.

Fabricius, J.C. 1792. Entomologia Systematica emendata et aucta secundum classes, ordines, genera, species adjectis synonimis, locis, observationibus, descriptionibus. Hafniae.

Fisher, W. 1950. A revision of the North American species of beetles belonging to the family Bostrichidae. Miscellaneous Publication, Wasington, D.C.

Fowles, A.P., Alexander, K.N.A., and Key, R.S. 1999. The Saproxylic Quality Index: evaluating wooded habitats for the conservation of dead-wood Coleoptera. Coleopterist, 8:121-141.

Geoffroy, E.L. 1762. Histoire abrégée des Insectes qui se trouvent aux environs de Paris, dans laquelle ces animaux sont rangés suivant un ordre méthodique. Paris.

Girard, V., Schmidt, A.R., Struwe, S., Perrichot, V., Breton, G., and Néraudeau, D. 2009. Taphonomy and palaeoecology of mid-Cretaceous amber-preserved microorganisms from southwestern France. Geodiversitas, 31:152-163.

Grimaldi, D.A. and Engel, M.S. 2005. Evolution of the Insects. Cambridge University Press, Cambridge.

Grimaldi, D.A., Shedrinsky, A., and Wampler, T. 2000. A remarcable deposit of fossiliferous amber from the Upper Cretaceous (Turonian) of New Jersey, p. 1-76. In Grimaldi, D. (ed.), Fossil in amber, with particular reference to the Cretaceous of New Jersey. Buckhuys, Leiden.

Handlirsch, A. 1906-1908. Die fossilen Insekten und die Phylogenie der rezenten Formen. Ein Handbuch für Paläontologen und Zoologen. Wilhelm von Engelmann, Leipzig.

Hyvärinen, E., Kouki, J., and Martikainen, P. 2006. Fire and green-tree retention in conservation of Redlisted and rare deadwood-dependent beetles in finnish boreal forest. Conservation Biology, 20:17111719.

Ivie, M.A. 2002. Bostrichidae Latreille, 1802, p. 233-244. In Arnett, R.H., Thomas, M.C., Skelley, P.E., and Howard, F.J. (eds.), American beetles. Polyphaga: Scarabaeoidea through Curculionoidea. CRL Press LLC, Florida.

Johansson, T., Andersson, J., Hjältén, L., Dynesius, M., and Ecke, F. 2011. Short-term responses of beetle assemblages to wildfire in a region with more than 100 years of fire suppression. Insect Conservation and Diversity, 4:142-151.

Jurc, M., Ogris, N., Pavlin, R., and Borkovic, D. 2008. Forest as a habitat of saproxylic beetles on Natura 2000 sites in Slovenia. Revue d'Ecologie (Terra Vie), 63:53-66.
Kirejtshuk, A., Azar, D., Beaver, R., Mandelshtam, M., and $\mathrm{Nel}, \mathrm{A}$. 2009. The most ancient bark beetle known: a new tribe, genus and species from Lebanese amber (Coleoptera, Curculionidae, Scolytinae). Systematic Entomology, 32:101-112.

Kugelann, J.G. 1792. Verzeichniss der in einigen Gegenden Preussens bis jetzt entdeckten Käfer-Arten nebst kurzen Nachrichten von denselben. Neuestes Magazin für die Liebhaber der Entomologie, herausgegeben von David Hinrich Schneider, Stralsund.

Lak, M., Néraudeau, D., Nel, A., Cloetens, P., Perrichot, V., and Tafforeau, P. 2008. Phase contrast X-ray synchrotron imaging: opening access to fossil inclusions in opaque amber. Microscopy and Microanalysis, $14: 251-259$.

Larsson, S. 1978. Baltic Amber - a Palaeobiological Study. Entomonograph, 1:1-192.

Latreille, P.A. 1802. Histoire Naturelle, Générale et Particulière des Crustacés et des Insectes. Familles Naturelles des Genres. F. Dufart, Paris.

Lawrence, J.F. 2010. Bostrichidae Latreille, 1802, p. 209-217. In Leschen, R., Beutel, R., and Lawrence, J.F. (eds.), Handbook of zoology. Coleoptera, Beetles. Volume 2. Morphoogy and Systematics (Polyphaga partim). Walter de Gruyter, Berlin.

Lawrence, J.F. and Newton Jr., A.F. 1995. Families and subfamilies of Coleoptera (with selected genera, notes, references and data on family-group names), p. 779-1006. In Pakaluk, J. and Ślipiński, S.A. (eds.), Coleoptera: papers celebrating the 80th birthday of Roy A. Crowson. Muzeum i Instytut Zoologii PAN, Warszawa.

Lesne, P. 1896. Révision des Coléoptères de la famille des Bostrychides. Annales de la Société Entomogique de France, 65:95-127.

Lesne, P. 1897. Révision des Coléoptères de la famille des Bostrychides. Annales de la Société Entomologique de France, 66:319-351.

Lesne, P. 1898. Révision des Coléoptères de la famille des Bostrychides. Annales de la Société Entomologique de France, 67:438-621.

Linnaeus, C. 1753. Species Plantarum. Stockholm.

Linnaeus, C. 1758. Systema Naturae per Regna Tria Naturae, seundum Clases, Ordines, Genera, Species, cum Characteribus, Differentis, Synonymis, Locis. Editio Decima, Reformata. Laurentii Salvii, Holmiae.

Liu, L.Y. and Schönitzer, K. 2011. Phylogenetic analysis of the family Bostrichidae auct. at suprageneric levels. Mitteilungen Muenchener Entomologischen Gesellschaft, 101:99-132.

Loudon, J.C. 1838. Arboretum et Fruticetum Britannicum. London.

Martínez-Delclòs, X., Briggs, D., and Peñalver, E., 2004. Taphonomy of insects in carbonates and amber. Palaeogeography, Palaeoclimatology, Palaeoecology, 203:19-64. 
McKellar, R., Wolfe, A., Muehlenbachs, K., Tappert, R., Engel, M., Cheng, T., and Sánchez-Azofeita, G. 2011. Insect outbreaks produce distinctive carbon isotope signatures in defensive resin and fossiliferous ambers. Proceedings of the Royal Society B: Biological Sciences, 278:3219-3224.

Miller, P. 1754. The Gardeners Dictionary. London.

Najarro, M., Peñalver, E., Pérez-de la Fuente, R., Ortega-Blanco, J., Menor-Salván, C., Barrón, E., Soriano, C., Rosales, I., López del Valle, R., Velasco, F., Tornos, F., Daviero-Gomez, V., Gomez, B., and Delclòs, X. 2010. Review of the El Soplao amber outcrop, Early Cretaceous of Cantabria, Spain. Acta Geologica Sinica, 84:959-976.

Néraudeau, D., Perrichot, V., Dejax, J., Masure, E., Nel., A., Philippe, M., Moreau, P., Guillocheau, F., and Guyot, T. 2002. Un nouveau gisement à ambre insectifère et à végétaux (Albien terminal probable): Archingeay (Charente-Maritime, France). Geobios, 35:233-240.

Ortega-Blanco, J., Peñalver, E., Delclòs, X., and Engel, M. 2011. False fairy wasp in Early Cretaceous amber from Spain (Hymenoptera: Mymarommatoidea). Palaeontology, 54:511-523.

Paykull, G. 1800. Fauna Suecica, Insecta (Coleoptera), Vol. 3. Upsala.

Penney, D. 2010. Dominican amber, p. 22-41. In Penney, D. (ed.), Biodiversity of fossils in amber from the major world deposits. Siri Scientific Press, Manchester.

Peñalver, E. and Delclòs, X. 2010. Spanish amber, p. 236-270. In Penney, D. (ed.), Biodiversity of fossils in amber from the major world deposits. Siri Scientific Press, Manchester.

Pérez-de la Fuente, R., Delclòs, X., Peñalver, E., Speranza, M., Wierzchos, J., Ascaso, C., and Engel, M. 2012. Early evolution and ecology of camouflage in insects. Proceedings of the National Academy of Sciences of the USA, 119:21414-21419.

Peris, D., Philips, T.K., and Delclòs, X. 2014. Ptinid beetles from the Cretaceous gymnosperm-dominated forests. Cretaceous Research, DOI: 10.1016/j.cretres.2014.02.009

Perrichot, V. 2004. Early Cretaceous amber from southwestern France: insight into the Mesozoic litter fauna. Geologica Acta, 2:9-22.

Perrichot, V., Néraudeau, D., and Tafforeau, P. 2010. Charentese amber, p. 192-207. In Penney, D. (ed.), Biodiversity of fossils in amber from the major world deposits. Siri Scientific Press, Manchester.

Poinar, G.O. 1992. Life in Amber. Stanford University Press, California.

Poinar, G.O. 2013. Discoclavata dominicana n. gen., n. sp., (Coleoptera: Bostrichidae) and Lissantauga epicrana n. gen., n. sp. (Coleoptera: Ecumenidae) in Dominican amber. Historical Biology, 25:107-113.

Poinar, G.O. and Poinar, R. 1999. The Amber Forest: $A$ Reconstruction of a Vanished World. Princeton University Press, Princeton.
Rasnitsyn, A.P. and Quicke, D.L. 2002. History of Insects. Kluwer Academic Publishers, Dordrecht, The Netherlands.

Ross, A., Mellish C., York, P., and Crighton, B. 2010. Burmese amber, p. 208-235. In Penney, D. (ed.), Biodiversity of fossils in amber from the major world deposits. Siri Scientific Press, Manchester.

Seyfullah, L.J., Beimforde, C., Perrichot, V., Rikkinen, J., and Schmidt, A.R. 2012. The what and why of amber: attempting to understand the relationship between resin production and amber deposits. In Witzmann, F. and Aberhan, M. (eds.), Centenary Meeting of the Paläontologische Gesellschaft - Programme, abstracts, and field guides. Terra Nostra, 2012/3:166-167.

Sinclair, B.J. and Kirk-Spriggs, A.H. 2010. Alavesia Waters and Arillo - A Cretaceous-era genus discovered extant on the Brandberg Massif, Namibia (Diptera: Atelestidae). Systematic Entomology, 35:268276.

Solórzano-Kraemer, M. 2007. Systematic, palaeoecology, and palaeobiogeography of the insect fauna from the Mexican amber. Palaeontographica, Abteilung $A, 282: 1-133$.

Soriano, C., Archer, M., Azar, D., Creaser, P., Delclòs, X., Godthelp, H., Hand, S., Jones, A., Nel, A., Néraudeau, D., Ortega-Blanco, J., Pérez-de la Fuente, R., Perrichot, V., Saupe, E., Solórzano-Kraemer, M., and Tafforeau, P. 2010. Synchrotron X-Ray imaging of inclusions in amber. Comptes Rendus Palevol, 9:361-368.

Spahr, L. 1981. Systematischer Katalog der Bernstein und Kopal-Käfer (Coleoptera). Stuttgarter Beiträge zur Naturkunde (B), 80:1-107.

Stephens, J.F. 1830. Illustrations of British Entomology. Mandibulata Vol. 3. London.

Tafforeau, P., Boistel, R., Boller, E., Bravin, A., Brunet, M., Chaimanee, Y., Cloetens, P., Feist, M., Hoszowska, J., Jaeger, J.-J., Kay, R.F., Lazzari, V., Marivaux, L., Nel, A., Nemoz, C., Thibault, X., Vignaud, P., and Zabler, S. 2006. Applications of X-ray synchrotron microtomographyfor non-destructive 3D studies of paleontologicalspecimens. Applied Physics A, 83:195-202.

Thompson, G.C. 1863. Skandinaviens Coleoptera, Synoptiskt Bearbetade. Lundbergska Boktryckeriet, Lund.

Toivanen, T. and Kotiaho, J. 2009. The preferences of saproxylic beetle species for different dead wood types created in forest restoration treatments. Canadian Journal of Forest Research, 40:445-464.

Waterhouse, C.O. 1888. New species of Lucanidae, Cetoniidae, and Buprestidae in the British Museum. The Annals and Magazine of Natural History, 1:260264.

Wickham, H.F. 1912. A report on some recent collections of fossil Coleoptera from the Miocene Shales of Florissant. Bulletin from the Laboratories of Natural History of the State University of lowa, 6:3-38. 